\title{
EVALUASI DESAIN KAPAL PATROLI - OPV BERBASIS RCS UNTUK MENGURANGI PANTAUAN RADAR LAWAN
}

\section{DESIGN EVALUATION OF OFFSHORES PATROL VESSEL RADAR CROSS SECTION FOR DECREASING ENEMY RADAR DETECTION}

\author{
Aditya Inzani, Samudro, dan Adrian Zulkifi \\ Pusat Teknologi Industri Pertahanan dan Keamanan \\ Deputi Teknologi Industri Rancang Bangun dan Rekayasa - BPPT \\ Ged. Rekayasa Teknologi Hankam No. 256 PUSPIPTEK - Serpong, Tang. Selatan - 15314 \\ e-mail : aditya.inzani@bppt.go.id, samudro@bppt.go.id; Adrian.zulkifi@bppt.go.id
}

\begin{abstract}
Abstrak
Sebagai negara kepulauan Indonesia memerlukan armada kapal perang nasional yang kuat untuk menjaga kedaulatan NKRI, mengamankan serta melindungi seluruh wilayah yurisdiksi perairan Indonesia. Ditinjau aspek geografi strategis, wilayah perairan Indonesia terbuka dikelilingi perairan internasional, berpotensi rawan konflik dan ancaman dari luar. Karenanya diperlukan sarana kapal-kapal perang yang berfungsi sebagai kapal patroli lepas pantai dari berbagai ukuran sesuai misi dan penugasan operasi perang maupun patroli. Kapal perang atau kapal patroli sebagai kapal permukaan perlu memiliki karakteristik desain lambung khusus untuk penyamaran, tidak mudah dipantau radar musuh saat beroperasi. Untuk itu pada karya ilmiah ini dilakukan kajian evaluasi desain kapal perang atau kapal patroli menggunakan prediksi nilai Radar Cross Section (RCS) lambung kapal. Pada penilaian RCS digunakan metode Shooting and Bouncing Ray (SBR) berdasarkan pendekatan Geometrics optics, memanfaatkan propagasi cahaya sebagai gelombang elektromagnetik lurus, dianalisa kekuatan arus serta dihitung besar dan arah pantulannya. Semakin besar nilai RCS suatu objek bangunan kapal, akan semakin mudah kapal dideteksi radar musuh. Hasil kajian penilaian RCS pada desain kapal KC-OPV60 dibandingkan nilai standar kapal ukuran $60 \mathrm{~m}$ menunjukan nilai RCS masih setara dan memenuhi ketentuan. Dengan lebih memperkecil penilaian RCS desain kapal, diharapkan kapal perang/ kapal patroli akan mampu beroperasi secara optimal dalam menjalankan misi operasi secara aman tanpa terdeteksi radar.
\end{abstract}

Kata Kunci : Desain Kapal Patroli, Lambung Kapal, Radar Cross Section (RCS)

\begin{abstract}
As the archipelago country, Indonesia requires strong fleet of national warship to preserve the sovereignty of the Republic of Indonesia, to secure and protect the entire jurisdiction Indonesian waters. Judging aspects of strategic geography, the Indonesian waters surrounded by open international waters, potentially prone to conflict and the threat from the outside. Therefore required a means of warships that served as offshore patrol vessels of various sizes according to the mission and assignment of the war and patrol operations. Warships or offshore patrol vessel as surface ships need to have special characteristics hull design for stealth, not the enemy radar is easily monitored during operation. For the purpose in this paper conducted an evaluation study of the design of warships or patrol boats using the predictive value of Radar Cross Section (RCS) of the hull. On RCS assessment method is used Shouting and Bouncing Ray (SBR) based Geometrics optics approach, utilizing the propagation of light as an electromagnetic wave straight, analysed the
\end{abstract}


current strength and calculation of direction as well as a large reflection. The greater the value of the ship building RCS of an object, the easier it will be identified by enemy radar. Results RCS assessment study on the design of the $K C$-OPV60 ship than the value of RCS standard vessel size $60 \mathrm{~m}$ showed the value of RCS still equivalent and compliant. RCS far more votes to the ship design, is expected to warships / patrol boats will be able to operate optimally in running operations missions safely without identify by enemy radar.

Keyword: Patrol Vessel Design, Hull, Radar Cross Section (RCS)

Diterima (received ) : 02 Oktober 2018

Disetujui (accepted) : 18 Juni 2019

\section{PENDAHULUAN}

Indonesia sebagai negara kepulauan yang berdaulat dengan luas wilayah laut yang terbuka lepas terhubung dengan perairan internasional, hal tersebut menjadikan wilayah perairan luar sekeliling Indonesia menjadi potensi rawan konflik, akibat ancaman serta gangguan keamanan dari berbagai kepentingan luar. Gambar 1 menunjukan wilayah geostrategis Indonesia terhubung dengan perairan internasional melalui tiga jalur Alur Laut Kepulauan Indonesia (ALKI).

Untuk mempertahankan kedaulatan dan menjaga keamanan seluruh wilayah perairan yurisdiksi nasional termasuk perairan lepas pantai perbatasan, dibutuhkan armada kapal perang maupun kapal patroli kelas Offshore Patrol Vessel (OPV) ${ }^{1)}$. Pengoperasian kapal
, Direvisi (revised ) : 25 April 2019 ,

perang/ kapal patroli dengan misi strategis dan rahasia perlu ditunjang dengan kondisi kapal dan peralatan teknis sebagai alat utama sistem persenjataan (alutsista) yang memadai. Salah satu upaya untuk menjaga keamanan dan kerahasiaan operasi kapal perang/ kapal patroli dari pantauan radar lawan adalah menggunakan teknik penyamaran (camoflage) pada bentuk lambung kapal. Beberapa inovasi teknologi geometric optic dapat digunakan untuk teknik penyamaran bentuk kapal dari pantauan radar 2). Salah satunya adalah melalui penerapan prediksi nilai Radar Cross Section (RCS) serta penggunaan rancangan bentuk struktur stealth maupun pelapisan/ pengecatan struktur kapal berbahan cat anti radar seperti Ni-coating glass untuk penyerapan efektif gelombang radar pada $\mathrm{C}$ - Ku band dalam $\mathrm{GHz}^{3,4)}$.

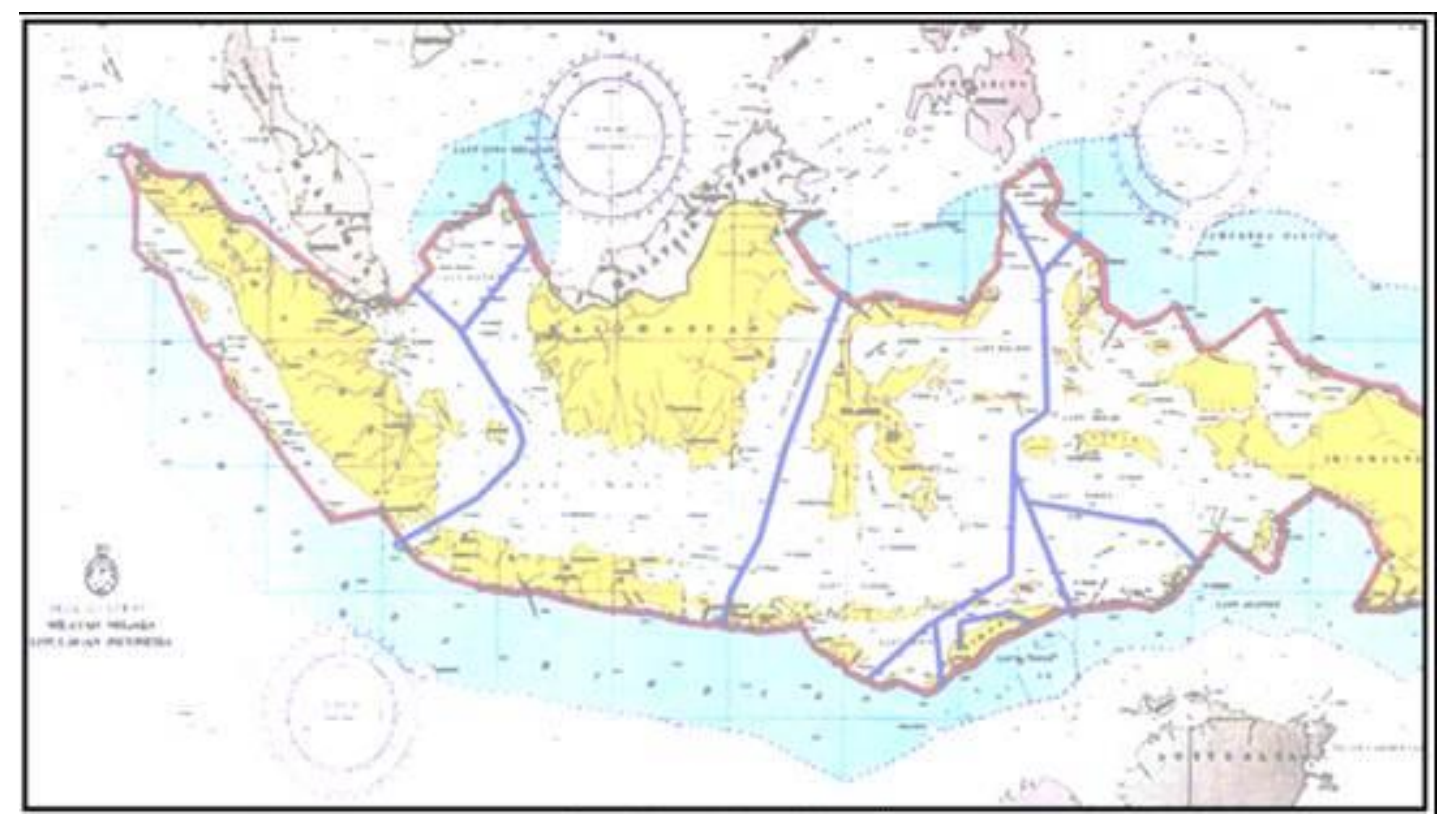

Gambar 1.

Peta Wilayah Geostrategis NKRI dengan Lintasan 3 Jalur ALKI dari Utara-Selatan 
Bila berpaling kebelakang dari sejarah pertempuran laut Aru dapat dikaji, ketika kapal perang MTB - KRI Macan Tutul gagal menjalankan misi operasi penyusupan pasukan gerilyawan RI ke Irian Barat karena terdeteksi oleh radar pesawat terbang patroli dan kapal perang Belanda seperti dokumen foto Gambar 2. Peristiwa ini mengakibatkan korban KRI Macan Tutul tenggelam akibat tembakan meriam kapal perang Belanda ${ }^{5)}$. Seandainya saat itu teknologi RCS sudah diterapkan pada kapal perang Indonesia, Kapal MTB KRI Macan Tutul mungkin tidak terdeteksi dengan jelas.

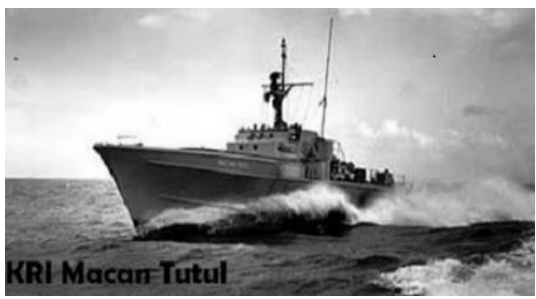

Gambar 2.

MTB - KRI Macan Tutul

Sumber : Dinas Penerangan TNI AL

Saat ini dengan berkembangnya inovasi teknologi RCS, resiko peristiwa pertempuran tersebut dapat dihindarkan dengan pemanfaatan material cat anti radar pada kapal perang. Untuk itu dalam suatu rangkaian kegiatan rancang bangun kapal perang/ kapal patroli lepas pantai perlu dilakukan terlebih dahulu kajian evaluasi karakteristik desain lambung dan bangunan atas kapal melalui penerapan prediksi RCS serta dilakukan upaya meminimalkan nilai RCS untuk desain lambung kapal. Untuk melakukan pengukuran nilai RCS yang sebenarnya pada suatu objek kapal perang akan membutuhkan tahap kegiatan yang rumit dan pembiayaan yang tinggi. Oleh karenanya perhitungan pendekatan dan keakuratan simulasi prediksi penting dalam perhitungan nilai RCS. Pada kajian dalam tulisan ini dilakukan simulasi penilaian prediksi RCS dengan berbagai variasi sudut dan bidang pantau radar pada desain kapal perang/ kapal patroli lepas pantai ukuran 60 $m$ yang dibangun di galangan kapal Indonesia. Dari hasil evaluasi ini diharapkan dapat digunakan sebagai masukan dalam peningkatan kualitas hasil rancang bangun kapal perang.

\section{BAHAN DAN METODE}

\section{Materi}

Pada kajian materi evaluasi RCS di sini digunakan materi rancangan kapal jenis combatan $60 \mathrm{~m}$ (KC-OPV60) yang mampu dioperasikan berpatroli pada wilayah perairan luar - lepas pantai. Kapal jenis tersebut sering disebut kelas Offshore Patrol Vessel (OPV). Pada Gambar 3 ditampilkan rancangan kapal jenis combatan $60 \mathrm{~m}$ serta pada Tabel 1 ditampilkan ukuran utama kapal KC-OPV60 6).

Tabel 1.

Ukuran Utama Kapal Patroli OPV60

\begin{tabular}{clc}
\hline No & Item Ukuran Utama & Ukuran \\
\hline 1 & Panjang total / Loa & $60 \mathrm{~m}$ \\
2 & Lebar total/ Boa & $8,1 \mathrm{~m}$ \\
3 & Tinggi geladak/ H & $4,5 \mathrm{~m}$ \\
4 & Sarat air/ T & $2,5 \mathrm{~m}$ \\
5 & Bobot/ D & $500 \mathrm{Ton}$ \\
6 & Kecepatan Patroli & $15 \mathrm{Knot}$ \\
7 & Kecepatan Jelajah & $20 \mathrm{Knot}$ \\
8 & Kecepatan maksimal & $28 \mathrm{Knot}$ \\
9 & Ketahanan operasi & \pm 5 Hari \\
10 & Kehandalan & Sea State 6 \\
\hline
\end{tabular}

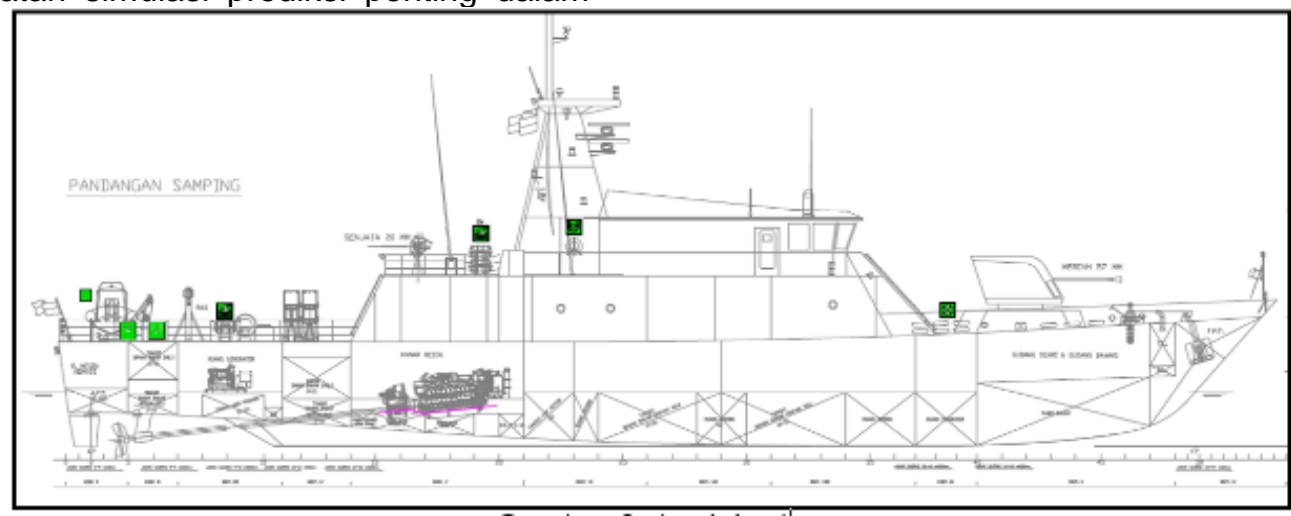

Gambar 3.

Desain Kapal Patroli OPV Combat 60 


\section{Metodologi}

Dalam kajian evaluasi karakteristik lambung kapal perang/ kapal patroli ini digunakan prediksi nilai RCS rancangan lambung kapal, dihitung menggunakan metode SBR berdasarkan pendekatan geometric optic. Geometric optic memiliki análisis yang lebih cepat dikarenakan menggunakan dasar Hukum optik Snellius ${ }^{7)}$.

Pada pelaksanaan kajian tersebut dimulai dari tahap ke (1), (2), (3) sampai ke (4) dengan setiap tahap dilakukan analisa berdasarkan masukan dari tahap sebelumnya.

\section{$>$ Tahap (1)}

Dilakukan kajian misi pengoperasian kapal jenis combatan $60 \mathrm{~m}$ (KC-OPV60) sebagai kapal patroli dengan tugas patroli pertahanan dan pengamanan di wilayah perairan yurisdiksi terluar NKRI yang berbatasan dengan wilayah perairan bebas internasional. Sesuai dengan spesifikasi teknis dan karakteristik desain bentuk lambung dan material struktur kapal, KCOPV60 harus mampu melaksanakan misi tanpa diketahui oleh radar lawan. Untuk itu pada tahap ini perlu dilakukan evaluasi karakteristik menyangkut bentuk desain, material struktur dan pelapis dinding bangunan atas kapal.

\section{$>$ Tahap (2)}

Dilakukan perhitungan komputasi nilai RCS dengan menggunakan perangkat lunak Computer Simulation Tecgnology (CST) untuk bentuk desain lambung dan bangunan atas KC-OPV60 melalui metode SBR 7). Dengan metode SBR dilakukan simulasi pemindaian nilai gelombang elektromagnetik yang dipantulkan kapal KC-OPV60 sebagai objek akibat pancaran tersebar dari suatu sumber gelombang elektromagnetik/ radar pihak lawan. Dengan melakukan beberapa simulasi sudut pancar maupun besar frekuensi dari radar lawan, maka akan didapatkan nilai RCS kapal KC-OPV60. Disini dilakukan pemindaian untuk 5 sudut pancar, seperti data Tabel 2.

\section{Tahap (3)}

Dilakukan evaluasi hasil simulasi nilai RCS KC-OPV60 terkait bentuk lambung dan bangunan atas serta posisi hot-spot yang terjadi dari karena pemindaian oleh radar lawan ${ }^{8}$. Nilai RCS KC-OPV60 juga dibandingkan dengan ukuran nilai standar RCS kapal yang lain. Melalui nilai perbandingan tersebut akan dapat di tentukan nilai RCS KC-OPV60 paling optimum yang dapat digunakan.

\section{$>$ Tahap (4)}

Hasil simulasi nilai RCS KC-OPV60 digunakan sebagai acuan dalam rekomendasi perbaikan dan pengembangan karakteristik desain lambung KC-OPV60.

\section{Tinjauan Teori}

\subsection{Gambaran Umum RCS}

Kerekayasaan implementasi iptek melalui prediksi nilai Radar Cross Section (RCS) dari suatu objek sudah dimulai sejak Perang Dunia ke-2. Pihak militer yang terlibat dalam perang dunia berlomba untuk mendeteksi RCS kapal perang maupun pesawat tempur lawan. Nilai RCS adalah nilai kekuatan gelombang elektromagnetik yang dipantulkan oleh suatu objek, melalui salah satu cara tersebut pihak yang berperang menggunakan metode ini untuk mengetahui keberadaan lawan. Dengan kondisi pandangan mata - visual yang terbatas, maka penggunaan RCS adalah suatu cara yang paling efektif mendeteksi objek lawan.

Untuk mengukur nilai RCS dari suatu objek secara tepat membutuhkan pembiayaan yang sangat besar. Untuk melakukan pengujian di lapangan dalam pengukuran RCS suatu objek kapal diperlukan pembiayaan operasi pelayaran kapal dan penerbangan pesawat dan analisa data untuk pemindaian objek oleh radar. Karenanya pendekatan melalui perhitungan teknis, prediksi nilai RCS dan simulasi visual pada rancangan kapal sangat penting dalam evaluasi penilaian RCS ${ }^{9}$. Algoritma untuk mendapatkan nilai RCS yang akurat terus berkembang sehingga metode perhitungan RCS yang paling akurat pun berkembang. Oleh karena itu sebagai tahap awal harus digunakan prediksi aproksimasi sebagai cara efektif untuk mencari nilai RCS. Beberapa metode aproksimasi dasar digunakan untuk mendapatkan nilai RCS antara lain :

- Geometrical Optics

- Physical Optics

- Geometrical Theory of Diffraction

- Physical Theory of Diffraction

- Method of Equivalent Currents

\subsection{Metode Shooting and Bouncing Ray (SBR) \\ Metode Shooting and Bouncing Ray} (SBR) adalah suatu metode berdasarkan aplikasi Geometrics optics. Dalam teori 
geometrics optics, propagasi cahaya dianggap sebagai suatu sinar bergaris lurus. Cahaya juga merupakan gelombang elektromagnetik, sehingga untuk metode penilaian RCS dapat menggunakan metode SBR. Dalam penggunaan metode SBR diperlukan proses Scattering Analysis (SA) yang dilakukan dalam 3 tahap. Tahap (1) SBR (Shooting and Bouncing Ray) menandai arah gelombang bergerak setelah mengenai suatu objek. Tahap (2) dilakukan analis kekuatan arus dari gelombang yang sudah mengenai dari sebuah permukaan suatu objek. Tahap (3) Menghitung besar dan arah pantulan gelombang yang terjadi setelah mengenai suatu objek.

Pada Gambar 4, ditampilkan gambaran saat sebuah gelombang mengenai sebuah objek Model 3D. Untuk mendapatkan vektor arah dan besaran dari sinar pantul dapat dirumuskan dari persamaan (1) seperti rumus dasar hukum Snellius, sebagai berikut

$$
\overline{\boldsymbol{O}}=\overline{\boldsymbol{O}}_{\text {origin }}=x_{0} \hat{\boldsymbol{x}}+y_{0} \hat{y}+z_{0} \hat{z}
$$

Adapun arah vektor sinar pantul seperti pada persamaan (2)

$$
\widehat{D}=x_{d} \hat{x}+y_{d} \hat{y}+z_{d} \hat{z}
$$

Dimana;

$$
x_{d}^{2}+y_{d}^{2}+z_{d}^{2}=1
$$

Sehingga pada dasarnya metode SBR merupakan penerapan rumusan hukum Snellius.

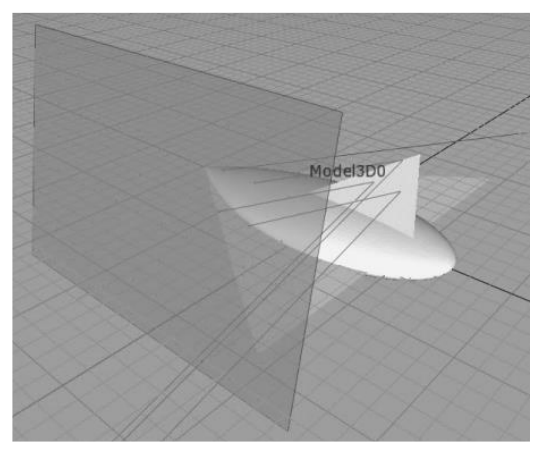

Gambar 4.

Tampilan gelombang datang ke objek

\subsection{Perhitungan Radar Cross Section (RCS)}

Dalam kegiatan perancangan kapal perang/ kapal patrol militer lepas pantai perhitungan nilai Radar Cross Section (RCS) sangat diperlukan. Nilai RCS akan menentukan besar kecilnya objek kapal terpantau sistem radar lawan dari jarak jauh.
Pada perhitungan RCS untuk mengevaluasi desain kapal perang/ kapal patrol yang dijadikan objek, digunakan perangkat lunak simulasi Computer Simulation Technology (CST). Dalam melakukan simulasi CST menggunakan metode Shooting Bouncing Ray (SBR) yaitu dengan menseleksi multi sudut pantul hamburan gelombang elektromagnetik dari objek 3D seperti dihambarkan pada Gambar 5. Melalui metode ini pantulan gelombang elektromagnetik yang mengenai objek didapatkan dengan cara menyeleksi/ menangkap gelombang yang terbaca dari salah satu sudut arah observasi. Dalam perhitungan nilai RCS factor air laut akan sangat berpengaruh. Hal ini dikarenakan air laut memiliki nilai permitivitas yang sangat tinggi $\quad(\varepsilon=80) \quad$ sehingga gelombang elektromagnetik ikut dipantulkan oleh air laut dalam pembacaan data. Untuk itu dalam perhitungan sebuah nilai RCS, faktor air laut harus ikut disertakan dalam komponen perangkat lunak perhitungan maupun pensimulasian.

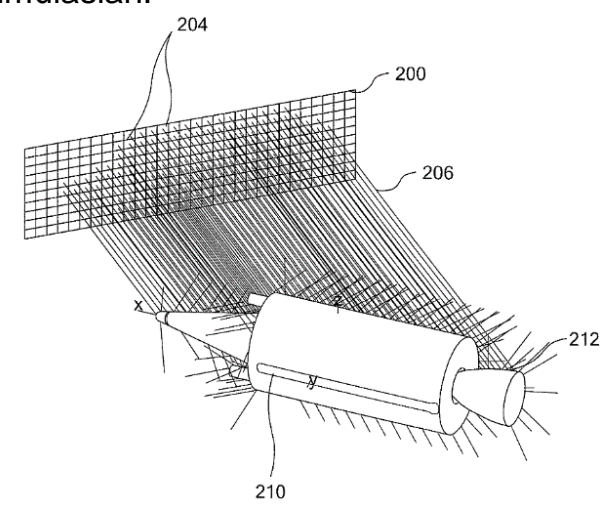

Gambar 5.

Penerapan metode SBR pada objek 3D multi sudut pantul

\subsection{Pembandingan Nilai Radar Cross Section (RCS)}

Pada perancangan bangunan kapal perang selalu dilakukan evaluasi nilai RCS lambung kapal serta dilakukan pembandingan nilai ini dari beberapa kapal perang sejenis. Nilai RCS ditulis dalam satuan luas $\left(\mathrm{m}^{2}, \mathrm{~cm}^{2}\right.$, atau $\left.\mathrm{km}^{2}\right)$ yang menyatakan luas pantulan gelombang elektromagnetik dari permukaan bidang kapal perang yang paling optimal. Dari data Gambar 6 dapat diamati, semakin besar ukuran kapal akan semakin besar nilai RCS yang dihasilkan. Untuk merancang sebuah kapal perang yang cukup besar perlu diperhatikan nilai RCS yang dihasilkan oleh kapal tersebut. Semakin besar nilai RCS maka semakin mudah kapal tersebut di deteksi oleh radar musuh. Kapal perang 
dirancang dengan menggunakan material logam, secara natural gelombang elektromagnetik yang memancar ke arah kapal dari radar lawan akan dipantulkan oleh kapal tersebut. Besar pantulan gelombang elektromagnetil dapat menjadi lebih besar ataupun berkurang tergantung dari bentuk bidang maupun jenis material kapal.

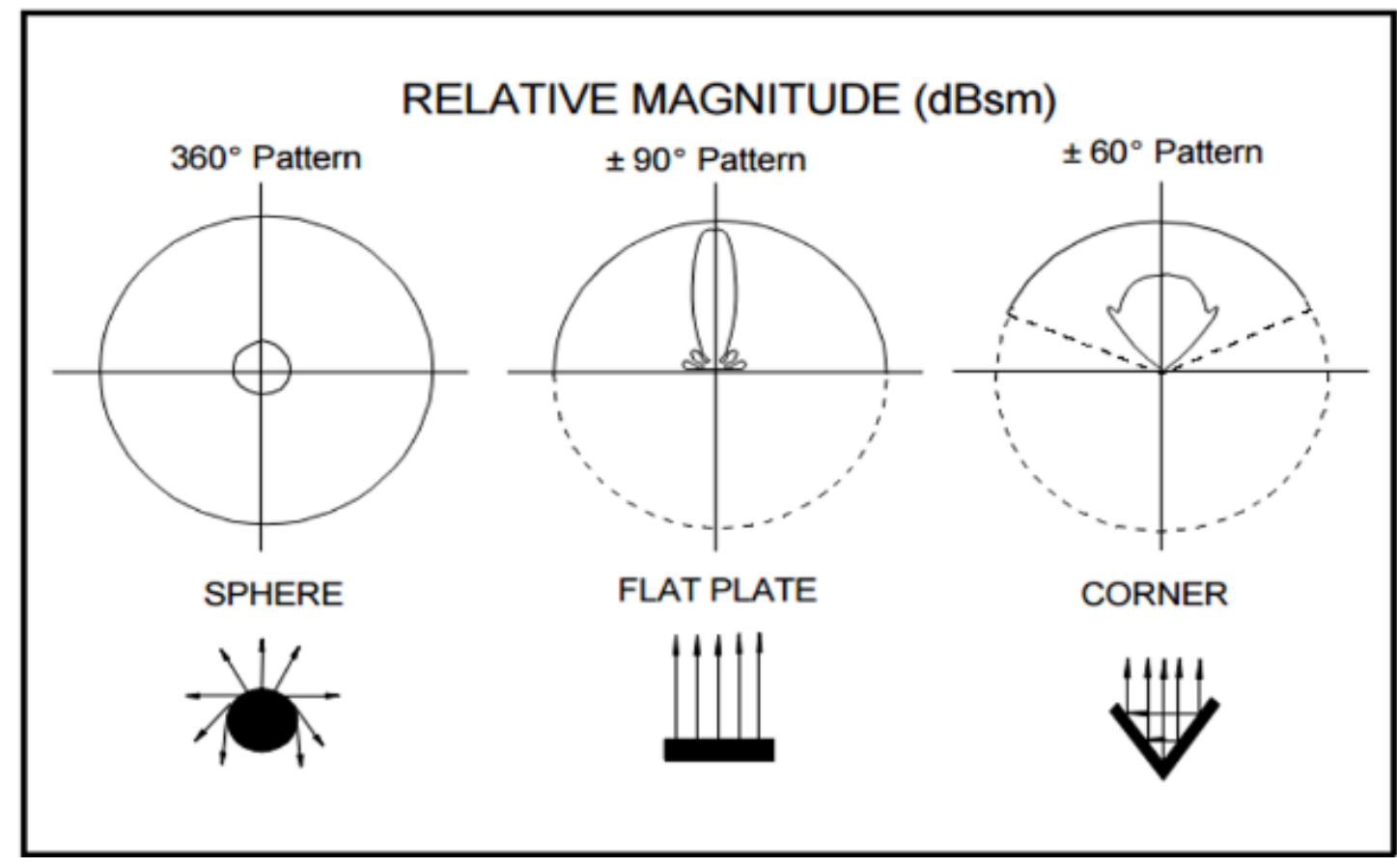

Gambar 6 .

Pengaruh Bentuk Objek terhadap Pantulan Gelombang Elektromagnetik

Pada objek berbentuk bola seperti pada Gambar 6, pantulan gelombang elektromagnetik akan terjadi sebesar bola itu sendiri. Sedangkan pada objek plat datar maka semua gelombang elektromagnetik akan dipantulkan ke arah sumber datang gelombang dengan fokus pada titik utama, sehingga nilai RCS akan terjadi lebih besar pada satu titik pusat ${ }^{10)}$.

Nilai RCS terbesar akan muncul pada bidang bersudut (corner reflector), pada bagian corner reflector akan muncul double bouncing ray yang disebabkan pemantulan dua kali. Hal ini menyebabkan nilai RCS akan besar pada area yang cukup luas sehingga objek akan mudah terdeteksi dari beberpa arah. Hal ini yang harus diperhatikan dengan membuang bidang sudut dan menggantikannya dengan bidang lengkung jika ingin membuat objek dengan nilai RCS yang kecil.

\section{Pembahasan}

\section{Simulasi nilai RCS}

Evaluasi nilai RCS rancangan kapal KCOPV60 dilakukan dengan menggunakan metode SBR, serta untuk mendapatkan nilai RCS model kapal KC-OPV60 disimulasi menggunakan software CST. Di sini frekuensi yang digunakan adalah frekuensi tinggi yang banyak dipakai pada radar pantai maupun radar pada kapal/ pesawat terbang meliputi: Frek. 2,3 GHz (S-Band), Frek. 5,3.

$\mathrm{GHz}(C-$-Band) dan Frek. $9.4 \mathrm{GHz}$ (XBand 11). Adapun hasil simulasi yang dilakukan menggunakan CST, dapat dllakukan analisis, menyangkut 3 hal: Nilai RCS, Bentuk RCS serta daerah Hotspot yang terjadi. Daerah Hotspot adalah bagian dari objek pengamatan radar yang banyak terjadi pantulan. Dalam melakukan simulasi menggunakan CST, medan elektromagnetik E dipancarkan sejajar dengan permukaan air laut. Hal ini dilakukan untuk mengurangi error yang terjadi karena timbulnya pantulan gelombang elektromagnetik dari air laut yang menggangu penilaian hasil pantulan sesungguhnya dari objek kapal. Simulasi RCS juga harus dilakukan dengan memvariasi sudut gelombang datang elektromagnetik: $0^{\circ}, 5^{\circ}, 10^{\circ}, 20^{\circ}$ dan $45^{\circ}$, seperti tercantum pada Tabel 2. Hal ini dimaksudkan untuk mengetahui efek yang terjadi jika gelombang radar datang dari arah atas kapal, seperti dari arah pesawat terbang.

Pada bagian di bawah ditampilkan contoh hasil evaluasi nilai RCS untuk 
rancangan lambung kapal KC-OPV60 dengan sudut pancar datang $0^{\circ}$ pemindaian gelombang elektromagnetik radar lawan ke arah haluan kapal.

\subsection{Simulai RCS pada Sudut datang $0^{\circ}$}

Pada simulasi RCS rancangan KCOPV60 ini sumber gelombang elektromagnetik memancar ke objek dari sudut datang $0^{\circ}$ atau dari arah haluan kapal (bow-side), sejajar dengan permukaan air laut. Bidang medan listrik dari gelombang elektromagnetik radar yang terjadi akan tegak lurus dan juga sejajar dengan permukaan air laut seperti visualisasi pada Gambar 7.

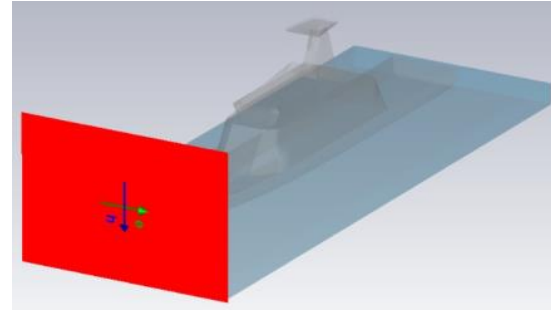

Gambar 7.

Sumber gelombang elektromagnetik datang dan arah medan magnitnya

Dengan menggunakan metode Shooting and Bouncing Ray maka didapatkan hasil simulasi nilai luasan RCS adalah sebesar $42,1 \mathrm{dBm}^{2}$ atau setara dengan $16.300 \mathrm{~m}^{2}$, sebagaimana ditampilkan pada Gambar 8 . Dari data standar nilai RCS untuk kapal dengan panjang sekitar $60 \mathrm{~m}$ adalah sebesar $1.000 \mathrm{~m}^{2}-16.000 \mathrm{~m}^{2}$. Nilai RCS tersebut masih sesuai dengan nilai yang disimulasikan pada rancangan kapal KCOPV60.

Monostatic Scattering RCS Abs (Phi=0)

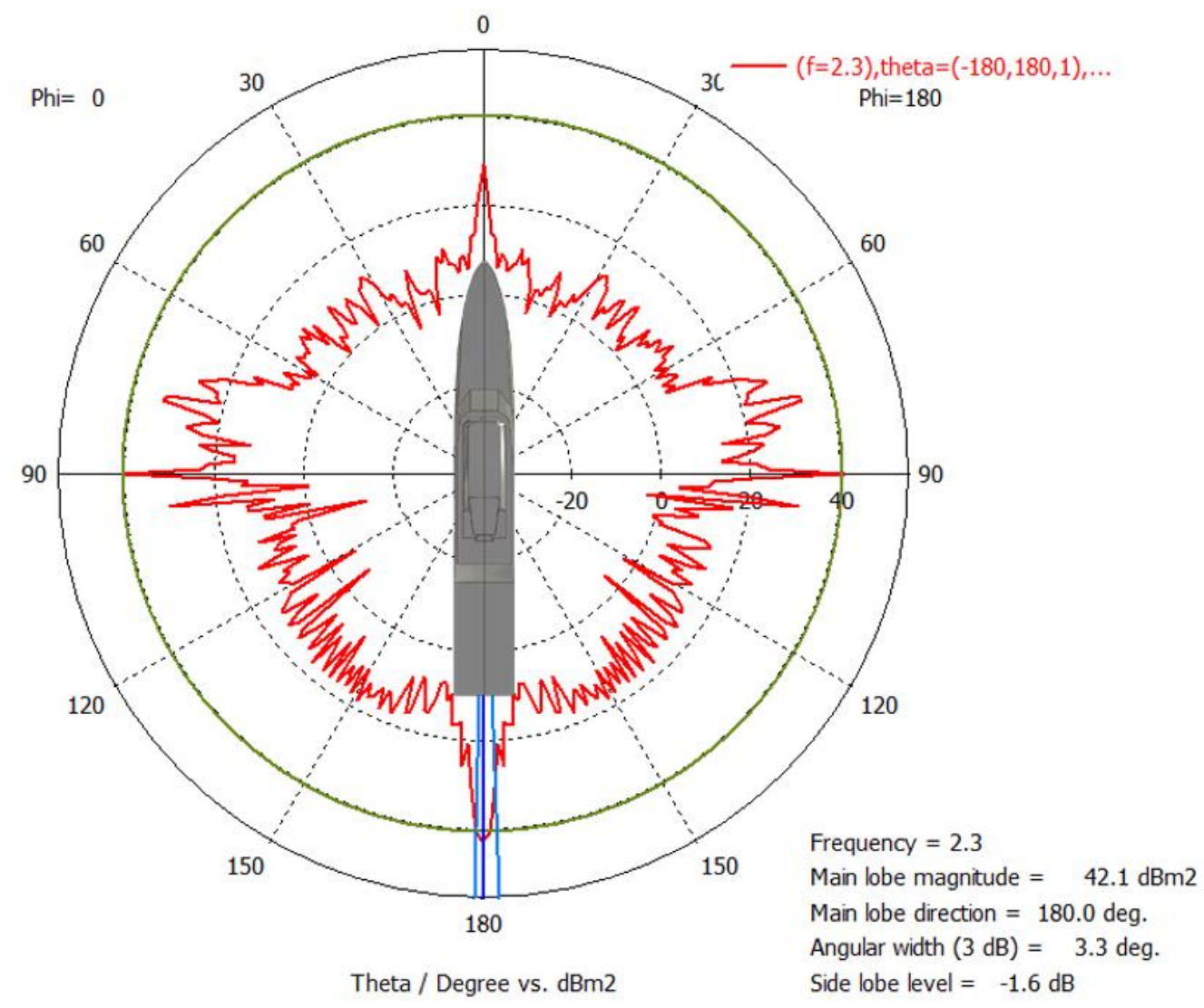

Gambar 8 .

Nilai RCS KC-OPV60 (sudut datang gelombang elektromagntik $0^{\circ}$ )

Selain dilakukan simulasikan nilai RCS, juga dapat dilakukan analisa lokasi bagian lambung kapal yang mempunyai kontribusi meningkatkan nilai RCS. Untuk itu dari simulasi CST dapat diperoleh penilaian daerah hotspot kapal yaitu dengan melakukan observasi pada bidang frontal lambung kapal dari setiap sudut observasi $10^{\circ}$ berputar berlawanan dengan arah jarum jam sebagaimana ditampilkan pada Gambar 11.a. Nilai pengamatan intensitas daerah 
hotspot pada suatu objek merupakan nilai non dimensional perbandingan antara intesitas pancaran gelombang elektromagnetik datang dan besar intensitas balikan/ refleksi gelombang yang ditangkap/ diobservasi kembali.

Hasil penilaian hotspot dari sudut observasi $0^{\circ}$ (bow-side) ke sudut observasi $180^{\circ}$ (stern-side) sebagaimana ditampilkan pada Gambar 9, Gambar 10 dan Gambar 11. Dari data simulasi CST dapat diperoleh hasil hotspot dari ke dua sisi kapal dari berbagai sudut observasi, meliputi nilai berkas datangnya gelombang elektromagnetik beserta pantulannya.

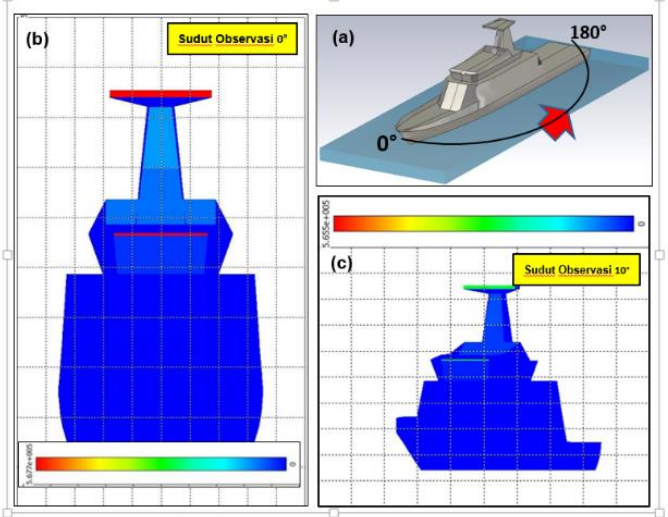

Gambar 9.

Arah putar sudut observasi dan Hasil penilaian Hotspot pada $0^{\circ}$ dan $10^{\circ}$.

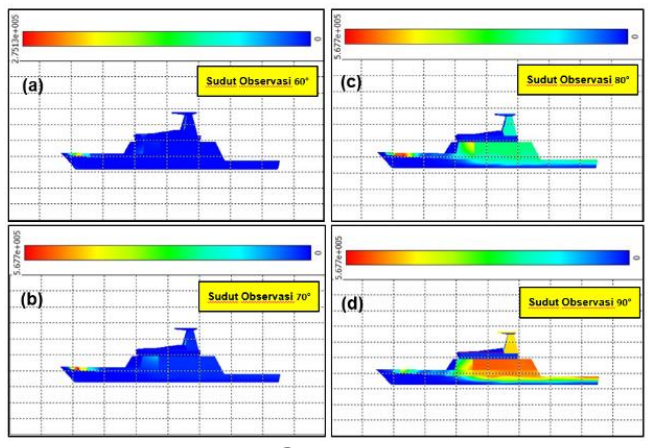

Gambar 10.

Hasil penilaian hotspot pada sudut observasi $60^{\circ}, 70^{\circ}, 80^{\circ}$ dan $90^{\circ}$

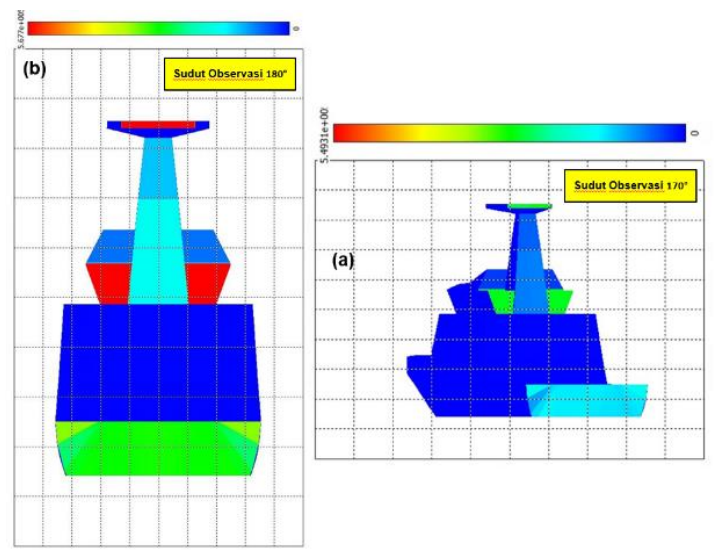

Gambar 11.

Hasil penilaian hotspot pada sudut observasi $170^{\circ}$ dan $180^{\circ}$.

Dapat terlihat nilai hotspot pantulan gelombang elektromagnetik terbesar ada di sudut $90^{\circ}$

Gambar 12 menampilkan hasil analisis pantulan gelombang elektromagnetik dari sudut datang $0^{\circ}$ ditinjau dari sudut observasi $90^{\circ}$ (melintang kapal). Disini terlihat pada beberapa bagian lambung kapal banyak gelombang elektromagnetik dipantulkan, terutama terjadi pantulan dari bagian sudut lambung di haluan dan di bangunan atas kapal. Hasil visualisasi dari pantulan gelombang elektromagnetik dapat dilihat menyebar dengan degradasi intensitas warna.

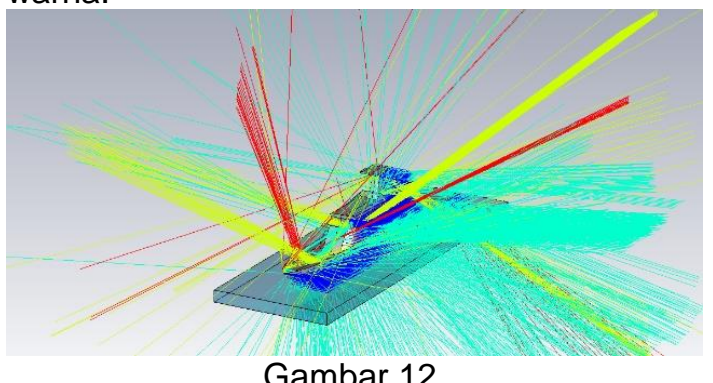

. Visualisasi pantulan berkas gelombang elektromagnetik (sudut observasi $90^{\circ}$ )

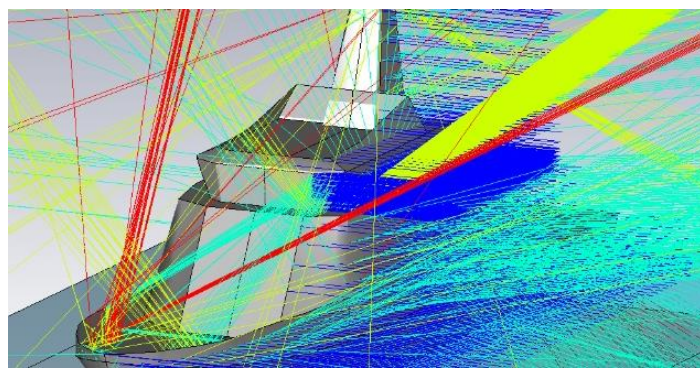

Gambar 13.

Visualisasi detail Gelombang elektromagnetik pada bangunan atas kapal

Dari Gambar 13 terlihat visualisasi garis biru tua adalah gelombang datang elektromagnetik dari sudut $0^{\circ}$ dari haluan kapal dan garis hijau, kuning dan merah merupakan visualisasi hasil pantulan dari gelombang datang dengan masing-masing merepresentasikan jumlah pantulan yang terjadi. Semakin sedikit jumlah pantulan maka nilai RCS akan menjadi relatif lebih kecil. Banyak pantulan (double bounce) terjadi yang merupakan refleksi atau pantulan dari bagian lambung kapal yang bersudut, maka bentuk kapal akan mudah dideteksi. Pada rancangan bagian sudut geladak haluan dan bagunan atas KC-LP60 
masih terlihat menghasilkan banyak pantulan dengan nilai intensitas tinggi.

1.2 Simulasi RCS pada sudut datang $5^{\circ}$, $10^{\circ}, 20^{\circ}$, dan $45^{\circ}$

Untuk mensimulasikan hasil penilaian RCS pada desain kapal patroli lepas pantai KC-OPV60 dengan asumsi adanya pemantauan oleh radar pesawat terbang, maka untuk hal tersebut dilakukan juga simulasi RCS dengan sudut datang gelombang elektromagnetik dari sudut $5^{\circ}$, $10^{\circ}, 20^{\circ}$, dan $45^{\circ}$. Hal ini untuk mengetahui bentuk perilaku pantulan gelombang elektromagnetik pada kapal dari pantauan radar pesawat terbang lawan sebagaimana ditampilkan pada Gambar 13. Hasil simulasi penilaian RCS ditampilkan pada Tabel 3. Dari hasil simulasi ini terlihat bahwa dari sudut datang $10^{\circ}$ dari pantauan radar musuh tampak luasan efektif yang terukur pada suatu objek lambung kapal akibat radiasi gelombang elektromagnetikyang terpancar terarah oleh suatu sumber incident power density menghasilkan nilai RCS terbesar $51.4 \mathrm{dbm}^{2}$ atau sebesar luasan $137.000 \mathrm{~m}^{2}$.

Tabel 3.

Hasil Simulasi penilaian RCS dari variasi sudut dating

\begin{tabular}{ccc}
\hline Sudut Datang & Nilai RCS & Luasan \\
\hline $0^{\circ}$ & $42,1 \mathrm{dbm}^{2}$ & $16.300 \mathrm{~m}^{2}$ \\
$5^{\circ}$ & $40,4 \mathrm{dbm}^{2}$ & $11.000 \mathrm{~m}^{2}$ \\
$10^{\circ}$ & $51,4 \mathrm{dbm}^{2}$ & $137.000 \mathrm{~m}^{2}$ \\
$20^{\circ}$ & $40,8 \mathrm{dbm}^{2}$ & $11.900 \mathrm{~m}^{2}$ \\
$45^{\circ}$ & $42,2 \mathrm{dbm}^{2}$ & $16.800 \mathrm{~m}^{2}$ \\
\hline
\end{tabular}

\section{SIMPULAN}

Penggunaan simulasi Radar Cross Section (RCS) untuk memprediksi nilai RCS suatu desain kapal perang/ kapal patroli militer sangat berperan penting dalam mendukung kemampuan hindar kapal dari pemantauan radar lawan dalam pelaksanaan misi operasi. Hasil simulasi penilaian RCS kapal KC-OPV60 dengan sudut datang pemindaian radar $0^{\circ}$ dari arah haluan, terutama pada sudut observasi $10^{\circ}$ menunjukan nilai RCS kapal tertinggi mencapai $51,4 \mathrm{dbm}^{2}$. Hal ini menunjukan bahwa desain kapal masih cukup baik terhadap pantauan radar kapal perang lawan, namun masih rentan terhadap pantauan radar pesawat terbang lawan.

Hasil penilaian hotspot kapal KC-OPV60 dari pantauan sudut datang pemindaian radar $0^{\circ}$ dari arah haluan, terutama pada arah sudut observasi $0^{\circ}-90^{\circ}$ menunjukan bahwa nilai hotspot pada dinding sisi bangunan atas dan pada sudut geladak haluan kapal mencapai nilai yang tinggi sehingga rentan terhadap pantauan radar lawan.

Sedangkan hasil penilaian hotspot kapal KC-OPV60 dari pantauan sudut datang pemindaian radar $0^{\circ}$ dari arah haluan, terutama pada arah sudut observasi $80^{\circ}$ $180^{\circ}$ secara umum menunjukan bahwa nilai hotspot pada lambung kapal, bangunan atas dan tiang mas kapal cukup rendah, namun pada bagian buritan menunjukan nilai yang meningkat sehingga rentan terhadap pantauan radar lawan. Hasil penilaian RCS pada desain kapal patroli lepas pantai KCOPV60 dibandingkan dengan nilai RCS kapal perang seukuran $60 \mathrm{~m}$ masih menunjukan nilai kesetaraan, berkisar $1000-16.000 \mathrm{~m}^{2}$. Hal mengindikasikan secara umum desain kapal KC-OPV60 mempunyai nilai RCS cukup baik.

\section{UCAPAN TERIMA KASIH}

Kajian simulasi Radar Cross Section (RCS) pada desain KC-OPV60 - BPPT merupakan bagian kegiatan Program Inovasi Teknologi Kapal Perang Nasional 2016 Pustekinhan BPPT dalam rangka mendukung penguasaan teknologi dan kemandirian rancang bangun kapal perang nasional. Untuk itu kami mengucapkan terimakasih kepada semua pihak yang ikut terlibat dalam kegiatan tersebut.

\section{DAFTAR PUSTAKA}

1. PERMENHAN No. 24/2010, Master Plan Revitalisasi Industri Pertahanan, Kementerian Pertahanan RI, Desember 2010.

2. Kim K, Kim J.H, Choi T.M, Cho D.S, Development of radar cross section of analysis system of naval ships, International Journal Naval Architect Ocean Engineering, No. 4, 2012, SNAK, South Korea.

3. C. Wang, M. Chen, H. Lei, K. Yao, H. Li, W. Wen, D. Fang, Radar stealth and mechanical properties of a broadband radar absorbing structure, journal Composites Part B. No. 123, 2017, Elsevier. 
4. Y.W. Nam, J. H. Choi, M.S. Jang, W.J. Lee, C.G. Kim, Radar-absorbing structure with nickel-coated glass fabric and its application to a wing aerofoil model, Journal Composite Structures No. 180, 2017, Elsevier.

5. Dispenal, Alutsista kebanggaan TNI AL dari masa ke masa, Buletin Sejarah TNI AL dan Kemaritiman : Info Historia, Vol. 4, No. 3 Okt-Des 2014, Markas Besar TNI AL - RI

6. A.I. Wahdiyat, Laporan Kajian simulasi Radar Cross Section pada desain Kapal Cepat Rudal-60 (KCR 60), Pustekinhan BPPT, Oktober 2017 (Tidak dipublikasikan).

7. E.F. Knott et. al, Radar Cross Section, Editor: Dedham, MA, Artech House, Inc. 1985.
8. L.Z. He, G. Xu at al, The research on calculation method of RCS of the electrically large scattering object, Journal of Senyang Institute of Aeronautical Engineering, SenyangChina, 2007.

9. E.F. Knott, A progression of highfrequency RCS prediction techniques, Proceeding of the IEEE, Vol. 73, No. 2, February 1985.

10. M. Skolnik, Radar Handbook $2^{\text {nd }} \mathrm{Ed}$. McGraw-Hill, Inc.USA, 1990.

11. Vaitheeswaran, S.M, Gowthami, T.S, Prasad S, Yathirajam B, Monostatic adar cross section of flying wing delta planform, Engineering Science and Technology, an International Journal, No. 20, 2017, Elsevier.

12. Williams, Cramp, Curtis, Experimental study of the radar cross section of maritime targets, Electronic Circuits and Systems, Vol. 2, No. 4,July 1978, amended by I. Harre, 2004. 